\title{
BEYOND TRAFFICKING AND SEXUAL EXPLOITATION: PROTECTING INDIA'S CHILDREN FROM INTER AND INTRA-FAMILIAL SEXUAL ABUSE
}

\author{
Jennifer Bays Beinart
}

\section{INTRODUCTION}

Child sexual abuse (CSA) has been documented throughout history. ${ }^{1}$ However, the willingness to recognize CSA as a problem has varied considerably. ${ }^{2}$ It was not until the 1960s and 1970s that the United States recognized CSA as a serious problem affecting its youth. ${ }^{3}$ As time passed, other nations began to acknowledge CSA as a significant social issue. ${ }^{4}$ Then, in 1989, the United Nations General Assembly adopted the Convention on the Rights of the Child (CRC) which called for the protection of children from all forms of sexual exploitation and abuse. ${ }^{5}$ Although the CRC has been ratified by every nation except Somalia and the United States, ${ }^{6}$ most countries continue to struggle to address CSA, whether

* Jennifer Bays Beinart is a 2011 J.D. candidate at Indiana University School of Law - Indianapolis. In 2006, she earned a Bachelor of Arts degree from Grinnell College. In 2004, Ms. Beinart studied in Puné, India for six months as part of the Associated Colleges of the Midwest India Study Abroad Program.

1. Sandy K. Wurtele \& Cindy L. Miller-Perrin, Preventing Child Sexual Abuse 1 (1992).

2. Id.

3. Id. at 3.

4. $I d$.

5. Convention on the Rights of the Child, G.A. Res. 44/25, U.N. Doc A/RES/44/25 (Nov. 20, 1989).

6. The United States signed the CRC on February 16,1995, but has yet to ratify the agreement. Convention on the Rights of the Child, opened for signature Nov. 20, 1989, 1557 U.N.T.S. 3, available at http://treaties.un.org/doc/Publication/MTDSG/Volume\%20V/ Chapter\%20IV/IV-11.en.pdf. When ratifying a treaty the United States evaluates the treaty's compliance with existing state and federal law and practice. Frequently Asked Questions Convention on the Rights of the Child, U.N.I.C.E.F., http://www.uniceforg/ crc/index_30229.html (last updated Feb. 10, 2006). This process often takes several years or longer if the treaty is politicized or controversial. Id. Additionally, the United States generally only reviews one human rights treaty at a time. Id. Currently, the United States is reviewing the Convention on the Elimination of All Forms of Discrimination against Women. Id. The Convention on the Elimination of All Forms of Discrimination against Women was signed by the United States on July 17, 1980, and has yet to be ratified by Congress. Convention on the Elimination of All Forms of Discrimination against Women, opened for signature Mar. 1, 1980, 1249 U.N.T.S. 13, available at http://treaties.un.org/ Pages/ViewDetails.aspx?src $=$ TREATY\&mtdsg_no=IV-8\&chapter $=4 \&$ lang-en. 
culturally or through their legislatures. ${ }^{7}$ India is no exception.

As of 2007, India was home to the world's largest number of sexually abused children: every 155 minutes, a child between the ages of ten and sixteen is raped, and every thirteen hours, a child younger than ten is raped. ${ }^{8}$ India is the largest democracy in the world with over 1.17 billion inhabitants, of which approximately thirty percent are fourteen years of age or younger. ${ }^{9}$ In India, fifty-three percent of all children, or 248 million children, have reported being sexually abused. ${ }^{10}$ The number of CSA victims in India is more than three times the number of children living in the United States."

With over half of India's children suffering from the emotional, physical, and mental effects of CSA, India's ability to thrive as a healthy and strong democracy is severely impaired. ${ }^{12}$ According to a 2007 study by the Indian Ministry of Women and Child Development, fifty percent of CSA is perpetrated by persons known to the child or in a position of trust and responsibility. ${ }^{13}$ India can no longer argue that CSA is a "Western

7. While it is hard to compare various prevalence studies due to differing methodology, CSA rates tend to be above ten percent in many western nations. See Table 1: Prevalence studies of child sexual abuse in different countries, NATIONAL SOCIETY FOR THE PREVENTION OF CRUELTY TO CHILDREN, http://www.nspcc.org.uk/Inform/research/briefings/ prevalencetablel_wdf49715.pdf (last visited Jan. 22, 2011); WURTELE \& MILLER-PERRIN, supra note 1 , at 6-10.

8. Loveleen Kacker, Srinivas Varadan, \& Pravesh Kumar, Ministry of Women AND Child Dev., Study on CHILd ABuse: INDIA 20077 (2007), available at http://wcd.nic.in/ childabuse.pdf.

9. The World Factbook: India, CIA, https://www.cia.gov/library/publications/theworld-factbook/geos/in.html (last visited Dec. 22, 2010).

10. Child Protection Issues, CHILDLINE INDIA FouND., http://www.childlineindia.org. in/cr_CPI_abuse_6.htm (last visited Dec. 22, 2010).

11. As of 2006, there were an estimated 73.7 million children under the age of 18 in the United States. Number of Children, ChILD TRENDS DaTABANK, http://www.childtrendsdatabank.org/pdf/53_PDF.pdf (last visited Dec. 22, 2010).

12. KACKER ET AL., supra note 8, at ii.

13. See id. at vii. This study was the first comprehensive CSA study in India and was ordered by the newly created Ministry of Women and Child Development in order to understand the "extent and magnitude of [CSA] in India." Id. at $i$. The Ministry began the study in 2005 , which covered thirteen Indian States with a sample size of 12,447 children (5 to 18 years of age), 2324 young adults (18 to 24 years of age), and 2449 stakeholders. Id. at iii, 15. Stakeholders were persons who held positions in government departments, private service, urban and rural local bodies, and individuals from the community. Id. at 16 . Stakeholders were included in order to survey the possible agencies to deal with child abuse. Id. The study examined four different types of abuse: physical, sexual, emotional, and girl child neglect. Id. at 14 . The study divided up participants into five different evidence groups: (1) children in a family environment, (2) children in school, (3) children at work, (4) children on the street, and (5) children in institutions. Id. at 15. The study attempted to maintain an equal number of boys and girls in each evidence group. Id. The data collection process took approximately six months. Id. at 17 . Data entry was done by a professional agency hired by the Ministry. $I d$. at 18 . The analysis of the data and writing of the report 
problem." by Western tourists or the sex trade, but also by family members and family friends. ${ }^{15}$ CSA is India's problem.

\section{ISSUE: INDIA'S CHILDREN LACK LEGAL PROTECTION AGAINST CHILD SEXUAL ABUSE}

Since the 1990s, several theories have attempted to explain India's high CSA rates. For example, many theorists point to India's outdated laws and unresponsive judiciary. ${ }^{16}$ Unlike the United States and most developed nations, India does not have explicit laws addressing inter-familial and intra-familial CSA, nor does India's penal code recognize incest as a crime. ${ }^{17}$ India's sexual offense laws penalize only rape, sodomy, unnatural offenses, ${ }^{18}$ and outrage against the modesty of a woman. ${ }^{19}$ The Indian Penal Code (IPC) has been criticized for its lack of punishment for crimes associated with a CSA case. ${ }^{20}$ Most of the applicable sections of the IPC impose a maximum prison sentence of two years and/or a fine. ${ }^{21}$

India's lack of explicit prohibitions against incest and CSA also

was completed by the Ministry. Id. at 19 . For the purpose of this study, sexual abuse was defined as "severe" and "other." Id. at 73. Severe forms of abuse included assault (including rape and sodomy), touching or fondling a child, exhibitionism (forcing a child to exhibit his/her body parts), and photographing a child in the nude. Id. Other forms included forcible kissing, sexual advances toward a child during travel, sexual advances toward a child during marriage situations, exhibitionism (exhibiting before a child), and exposing a child to pornography. Id. at 73 . Out of the total child respondents, $53.22 \%$ reported having encountered either a severe or other form of abuse. Id. at 74. See KACKER, ET AL., supra note 8, at 13-20 (additional information regarding the study methodology). In contrast, according to the 2010 Fourth National Incidence Study of Child Abuse and Neglect, twentytwo percent of children in the United States are sexually abused each year. ANDREA J. Sedlak et al, U.S. Dept. of Health \& Human Servs., Fourth National Incidence STUDY OF CHILD ABUSE AND NEGLECT (NIS-4) 6, 6-7 (2010).

14. KACKER ET AL., supra note 8, at 73.

15. See id. at 81 (stating that only twenty-one percent of children reported being abused by strangers or those they faintly knew).

16. E.g., Asha Bajpai, Child Rights In India: Law, Policy, and Practice 14 (2d ed.2006).

17. Shoma Chatterii, Incest and the Conspiracy of Silence, INDIA TOGETHER (Apr. 30, 2009), http://www.indiatogether.org/2009/apr/chi-incest.htm.

18. Section 377 of the Indian Penal Code states that "[w]hoever voluntarily has carnal intercourse against the order of nature with any man, woman or animal" commits an unnatural offense. PEN. CODE $\S 377$ (2010) (India). The explanation to this section requires that the penetration be "sufficient to constitute carnal intercourse." Id.

19. Chatterji, supra note 17.

20. Moily for Tough Law Against Child Sexual Abuse, Econ. Times (India) (Jan. 14, 2010, 04:04 AM IST), http://economictimes.indiatimes.com/news/politics/nation/Moily-fortough-law-against-sexual-abuse/articleshow $/ 5442354 . \mathrm{cms}$.

21. Neeta Lal, Hidden Darkness: Child Sexual Abuse in India, AsIA SENTINEL (May 2, 2007), http://www.asiasentinel.com/index.php?option=com_content\&task $=$ view\&id=476\& Itemid $=34$. 
affects India's compliance with the multinational CRC. ${ }^{22}$ The United Nations Committee on the Rights of the Child continues to express concern with India's outdated CSA laws. ${ }^{23}$ While India has addressed other issues concerning children such as child education, health and development, ${ }^{24}$ its CSA actions have been woefully inadequate. In order to comply with the $\mathrm{CRC}$, India must make changes to its antiquated laws and judicial procedures.

The first part of this Note provides a short introduction to CSA, discusses possible definitions of CSA, and discusses the recognition of CSA as a societal problem. The second part of this Note examines current CSA laws and the case of Sakshi $v$. Union of India. ${ }^{25}$ In addition, this part focuses on the United Nations Convention on the Rights of the Child, Indian Constitution, Indian Penal Code of 1860, Goa Children's Act and its Amendments, and the Commissions for the Protection of Child Rights Act. Finally, this Note discusses recommendations for India's Parliament and Executive to better tackle the problem of CSA in India while improving compliance with the CRC.

\section{BACKGROUND}

\section{A. What is CSA?}

There is little agreement on the appropriate definition of CSA. ${ }^{26}$ There are medical, psychological, legal, sociological, feminist, and moral definitions of CSA. ${ }^{27}$ Cultural differences may account for the varied CSA definitions. ${ }^{28}$ "Perceptions of what constitutes sexual abuse are culturally and socially determined, with the result that acts which are considered offensive in one cultural context may be quite normal in another." 29 Separate countries and/or cultures have different definitions of "child" and "sexual," which also highlight varying perceptions about the duration of childhood and a child's proper development. ${ }^{30}$

22. Comm. on the Rights of the Child, Consideration of Reports Submitted by States Parties Under Article 44 of the Convention, 35 U.N. Doc. CRC/C/15/Add.228 (Feb. 26, 2004).

23. $I d$.

24. Deepa Jain Singh, Foreword to LoveleEn Kacker, SRINIVAS Varadan, \& Pravesh Kumar, Ministry of Women and Child Dev., Study on Child Abuse: India 2007 ii (2007), available at $\mathrm{http}: / / \mathrm{wcd} . n i c . i n / c h i l d a b u s e . p d f$.

25. Sakshi v. Union of India \& Ors, A.I.R. 2004 S.C. 3566 (India).

26. Int'l Child Dev. Initiatives, Child Sexual abuse: What Can Governments Do? 3 (Rekha Wazir \& Nico van Oudenhoven eds., 1998).

27. Id.

28. Id.

29. Id.

30. Id. 
For example, “Age limits are a legal manifestation of a community's beliefs regarding the development of a child's capacities and responsibilities.... But age limits vary from activity to activity and country to country." establishing the prevalence of CSA have defined the term child using chronological age thresholds of sixteen, seventeen, or eighteen years. ${ }^{32}$ These thresholds correspond with other increased privileges in the United States such as driving, voting, having the option to drop out of school, and getting married. Across the world, legal definitions of childhood vary substantially; the legal age of consent for sexual activity spans from twelve in some parts of Mexico and the Philippines to twenty-one in Madagascar. ${ }^{33}$ Additionally, some countries, including Ecuador, North Korea, Oman, and Pakistan, do not have a legal age of consent for sexual activity. ${ }^{34}$

India, like the United States, has several different legal thresholds marking the end of childhood. The Census of India defines a child as a person below the age of fourteen. ${ }^{35}$ Passed during British rule, the Indian Majority $\mathrm{Act}^{36}$ defined a child as anyone under the age of eighteen, unless a particular personal law ${ }^{37}$ stated otherwise. ${ }^{38}$ The Child Marriage Restraint Act, the passage of which was due to British pressure to reduce the number of child marriages, defined the age of sexual consent for a female as sixteen if unmarried and fifteen if married. ${ }^{39}$ Later, the IPC was amended to mirror the legal definition of childhood from the Child Marriage Restraint Act and established the age of sexual consent for both males and females as sixteen, unless the child is married, in which case the age of sexual consent is fifteen. ${ }^{40}$

Defining the term "sexual" has also been plagued by a lack of uniformity. Most scholars and cultures agree that certain behaviors such as

31. BAJPAI, supra note 16 , at 2 .

32. Stephen Smallbone et al., Preventing Child Sexual Abuse: Evidence, POLICY, AND PRACTICE 2-3 (2008).

33. Id.

34. Id.

35. BAJPAI, supra note 16 , at 2.

36. Indian Majority Act, No.9 of 1875, INDIA CODE (2010).

37. Instead of a uniform civil code, India adopted four personal law systems: Hindu, Muslim, Christian, and Parsis. These personal laws cover subjects such as marriage, divorce, inheritance, adoption, and custody of children. Those who do not fall within one of the four religions specified may appeal either to general civil law, where such laws could be identified, or to Hindu personal law. Purushottam Bilimoria, Muslim Personal Law in India: Colonial Legacy and Current Debates, http://www.law.emory.edu/ifl/index2.html (last visited Dec. 22, 2010). See also Asha Bajpai, Custody and Guardianship of Children in India, 39 FAM. L.Q. 441 (2005) (discussing India's many religions and legal custody of children).

38. Indian Majority Act, No. 9 of 1875.

39. Child Marriage Restraint Act, No. 19 of 1929, INDIA CoDE (2010).

40. PEN. CODE $\S 375$ (2010) (India). 
genital stimulation or sexual intercourse qualify as sexual. ${ }^{41}$ However, there is less agreement as to whether the term sexual could extend to behaviors such as bathing or sleeping with a child, kissing a child, or massaging a child. ${ }^{42}$

The lack of uniformity in the definition of sexual has led to many generalized CSA definitions that attempt cross-cultural application. One widely-used definition describes CSA "as any kind of physical or mental violation of a child with sexual intent usually by a person who is in a position of trust or power vis-à-vis the child. ${ }^{, 43}$ Another source defines CSA as "any sexual behavior directed at a person under sixteen, without informed consent." $\$ 4$

\section{B. Acknowledgement of CSA as a recognized problem}

In the late nineteenth century, both charity and social workers in the United States were familiar with CSA and knew that the most common form was intra-familial CSA; however, the view of these workers, as well as the view of the general public, changed drastically in the early twentieth century. ${ }^{45}$

By the 1920's [sic] a three part transformation in attitude had occurred: [CSA] was perceived to be in the streets, rather than in the home, the perpetrator was perceived as a perverted stranger rather than a male family member, and the victim was perceived as a temptress rather than an innocent child. ${ }^{46}$

As a result of this change in perception, social workers de-emphasized incest and academics dismissed incest as being extremely rare, claiming that it occurred in only one in a million cases. ${ }^{47}$ Even though Indiana University professor and revolutionary sex researcher Alfred Kinsey's studies in the middle of the twentieth century established that incest and CSA were far from rare, Kinsey did not view CSA as problematic. ${ }^{48}$ Thus, while professionals acknowledged CSA was occurring, its consequences were minimized. ${ }^{49}$

The sexual revolution of the 1960 s and 1970 s led to a public

41. SMALlBONE ET AL., supra note 32, at 3.

42. Id.

43. BAJPAI, supra note 16, at 207.

44. Id.

45. WURTELE \& MILLER-PERRIN, supra note 1 , at 2.

46. Id.

47. Id.

48. Id.

49. Id. 
awareness of the problems of CSA. The sexual revolution created an atmosphere in which adults who had been victims were encouraged to discuss their experiences. ${ }^{50}$ As official reports of CSA increased and CSA began to receive unprecedented media coverage, the United States finally recognized that CSA was a serious problem. ${ }^{51}$

Conversely, CSA is still a taboo subject in India that is shrouded in a conspiracy of silence. ${ }^{52}$ Most Indians believe that CSA is largely a Western problem and that CSA does not occur in India. ${ }^{53}$ This disbelief can be partially explained by India's conservative family and community structure that does not allow discussion of sex and/or sexuality. ${ }^{54}$ Additionally, India has developed a culture that prizes virginity in female children. ${ }^{55}$ Many different cultural and social practices have been developed to protect a female child's purity prior to marriage. ${ }^{56}$ These practices include child marriage, segregating the sexes except in situations that can be observed by elders, and disfavoring marriage with a non-virgin female.

Most Indians believe that families and communities, as opposed to the government, are responsible for the care and protection of children. ${ }^{57} \mathrm{~A}$ strong patriarchal family rarely recognizes that children are individuals with their own rights. ${ }^{58}$ Rather, children are the responsibility of the male figurehead, who has the right to make decisions regarding his child's care and welfare.

In 1985, in order to address the needs of women and children, the Government of India created the Department of Women and Child Development in the Ministry of Human Resource Development. ${ }^{59}$ The Department of Women and Child Development pushed for a rights-based approach to bolster development and protection for women and children. ${ }^{60}$ In 2006, India made a firm commitment to a right-based approach to the development and advancement of India's women and children and upgraded the Department of Women and Children to a Ministry. ${ }^{61}$ Initial Ministry investigations revealed that India suffered serious gaps in child protection. ${ }^{62}$ Furthermore, the Ministry discovered that India had enormous

50. Id. at 3 .

51. Id.

52. KACKER ET AL., supra note 8, at 73.

53. Id.

54. Id.

55. $1 d$.

56. Id.

57. KACKER ET AL., supra note 8, at v.

58. Id.

59. About Us, MINISTRY OF WOMEN AND CHILD DEV., http://wcd.nic.in/ (last visited Dec. 22, 2010).

60. See KACKER ET AL., supra note 8, at v.

61. About Us, supra note 59.

62. KACKER ET AL., supra note 8, at v. 
numbers of children who needed care and protection. ${ }^{63}$

However, the Ministry has continually suffered from insufficient budgetary allocations and a lack of programs to protect children in need of services. $^{64}$ In the course of researching the needs of India's children, the Ministry observed that India's child protection scheme needed an enabling environment, constructed through legislation, to address issues of child abuse. $^{65}$ In addition, the Ministry recognized the need for a national policy on child protection that included procedures for interventions and outreach service. $^{66}$ In order to address these needs, the Ministry, in conjunction with Parliament, created the National Commission for the Protection of the Rights of the Child. ${ }^{67}$ The Ministry and Parliament also began to draft a bill to prevent offenses against children and construct a comprehensive national child protection scheme. ${ }^{68}$ During this process, a lack of data on offenses against children held back the Ministry's work. ${ }^{69}$ In order to understand the gravity of the problem, the Ministry initiated a national study on child abuse. $^{70}$ This study, as well as the increasing number of grown CSA victims speaking about their experiences, led India to realize that CSA is not just a western problem, but a global problem. ${ }^{71}$

\section{UNITED NATIONS CONVENTION ON THE RIGHTS OF THE CHILD (CRC)}

The CRC has three articles that address a government's responsibility to prevent CSA and other forms of child abuse. Article 19 requires governments to take all "appropriate legislative, administrative, social and educational measures" to protect children from CSA and incest. ${ }^{72}$ Protective measures, according to the CRC, should include "effective procedures for the establishment of social [programs] to provide necessary support for the child and for those who have the care of the child, as well as for other forms of prevention and for identification, reporting, referral, investigation, treatment, and follow-up." ${ }^{, 73}$ Article 34 requires governments

63. Id.

64. Id.

65. Id.

66. Id.

67. Id.

68. Id.

69. Id.

70. Id. Prior to this study, the only information available annually was the crime database managed by the National Crime Records Bureau. However, this information only included reported crimes under the India Penal Code (IPC). Id. at 8. This information is unreliable as most CSA goes unreported and incidents which are reported often do not qualify as crimes under the IPC. Id. at 9. See infra Part V.B.

71. KACKER ET AL., supra note 8, at 73.

72. Convention on the Rights of the Child, supra note 5, art.19.

73. Id. 
to protect children from all forms of sexual exploitation and abuse (CSA). ${ }^{74}$ Finally, Article 39 requires states to "take all appropriate measures to promote physical and psychological recovery and social reintegration of a child victim."75 Recovery measures are intended to foster respect for the "health, self-respect and dignity" of the child victim. ${ }^{76}$

Article 253 of the Indian Constitution allows Parliament to implement and ratify treaties. ${ }^{77}$ On November 12,1992 , India ratified the CRC. ${ }^{78}$ Additionally, the Supreme Court of India has held that "once signed, any international treaty will be treated as part of the law unless otherwise stated."79 Thus, once India signs a convention or treaty, India is bound to its obligation to implement that convention or treaty unless dictated otherwise. ${ }^{80}$ This enables all citizens to bring actions to enforce provisions of a signed agreement and to use the agreement's provisions to support legal arguments. ${ }^{81}$

\section{INDIA'S CURRENT CSA PROTECTIONS}

\section{A. Constitution}

India's Constitution "recognizes the vulnerable position of children and their right to protection." 82 Following the doctrine of protective discrimination, ${ }^{83}$ Article 15 of the Indian Constitution provides for special attention to children through laws and policies designed to safeguard their rights. ${ }^{84}$ Article 39 grants further protection, requiring the state to "direct its policy towards securing ... that children are given opportunities and facilities to develop in a healthy manner and in conditions of freedom and dignity and that childhood and youth are protected against exploitation and against moral and material abandonment."

74. Id. art. 34.

75. Id. art. 39.

76. $I d$.

77. INDIA CONST. art. 253.

78. BAJPAI, supra note 16 , at 23.

79. Id. at $14-15$.

80. Id. at 15

81. Id.

82. KACKER ET AL., supra note 8, at 23.

83. The doctrine of protective discrimination, also known as positive discrimination, provides special privileges to a particular group to offset societal discrimination. This doctrine is most often invoked for women and the scheduled castes of India. See TAMESHNIE Deane, Affirmative Action: A Comparative Study 264-70 (2005) (J.D. Thesis, University of South Africa), available at http://uir.unisa.ac.za/dspace/bitstream/10500/ 2012/2/09chapter8.pdf.

84. Article 15(c) states that "[n]othing in this article shall prevent the State from making any special provision for women and children." INDIA CONST. art. 15(c).

85. INDIA CONST. art. 39(f). 


\section{B. Laws and Statutes}

\section{Indian Penal Code of 1860}

The Indian Penal Code (IPC) is the primary code for all criminal offenses and punishment in India. The code has been described by some as archaic and sexist. ${ }^{86}$ However, the IPC does not directly address or recognize CSA. ${ }^{87}$ Furthermore, Indian laws fail to provide a clear legal definition of CSA ${ }^{88}$ The majority of CSA cases brought in India are tried under Section 375, which many argue is adequate to deal with CSA. ${ }^{89}$ Under Section 375, rape is defined as penile penetration in a vagina, which is sufficient to constitute sexual intercourse. ${ }^{90}$ Section 375 states:

A man is said to commit "rape" who . . . has sexual intercourse with a woman under circumstances falling under any of the six following descriptions:

First. - Against her will.

Secondly. - Without her consent.

Thirdly. - With her consent, when her consent has been obtained by putting her or any person in whom she is interested in fear of death or of hurt.

Fourthly. - With her consent, when the man knows that he is not her husband, and that her consent is given because she believes that he is another man to whom she is or believes herself to be lawfully married.

Fifthly. - With her consent, when, at the time of giving such consent, by reason of unsoundness of mind or intoxication or the administration by him personally or through another of any stupefying or unwholesome substance, she is unable to understand the nature and consequences of that to which she gives consent.

86. See Pinki Virani, Bitter Chocolate: Child Sexual Abuse IN INDia (2000).

87. PEN. CODE (2010) (India).

88. BAJPAI, supra note 16 , at 14.

89. See id. at 217-20.

90. The IPC explanation states that "[p]enetration is sufficient to constitute the sexual intercourse necessary to the offence of rape.” PEN. CODE $\S 375$ (2010) (India). However, this has been interpreted to require penetration of a sufficient force or depth to qualify as sexual intercourse. See Lal, supra note 21. 
Sixthly. - With or without her consent, when she is under sixteen years of age. ${ }^{91}$

The IPC does not recognize digital, oral, or object penetration, nor does it recognize the rape of a man by another man or woman. ${ }^{92}$ In addition, the IPC's definition of rape is highly dependent on medical evidence to support the allegation of penetration. ${ }^{93}$ Prior to 2000 , most courts stated that evidence of non-injury signified consent of the victim or the falsity of the claim. ${ }^{94}$ However, in 2000, the Supreme Court of India set aside a lower court ruling that acquitted an accused rapist on the grounds that the lack of injury to the victim was a material fact. ${ }^{95}$ As such, the high court held that it was probable that the victim had consented. ${ }^{96}$ Thus, with the Supreme Court's ruling, evidence of non-injury to the victim is no longer considered prima facie evidence of consent or falsity. ${ }^{97}$

Section 377 - unnatural offenses - is often invoked as a supplementary cause of action for CSA when penile penetration is not present. ${ }^{98}$ Under Section 377 , "[w]hoever voluntarily has carnal intercourse against the order of nature with any man, woman, or animal, shall be punished with imprisonment for life, or with imprisonment of either description for a term which may extend to ten years and shall also be liable to fine."99 Section 377 is most often used when male children are sexually abused. $^{100}$ Specifically, this section was designed to prevent sodomy and only applies to cases of penile penetration. ${ }^{101}$ Thus, this section does not cover acts such as sexual molestation, or digital and/or object penetration. ${ }^{102}$ Similar to Section 375 , the degree of penetration must be sufficient to constitute intercourse. ${ }^{103}$

Section 354 is the last resort for CSA victims when an offense cannot be prosecuted under Sections 375 or 377 . Section 354 criminalizes acts that outrage a person's modesty. ${ }^{104}$ Under Section 354, “[w]hoever assaults or uses criminal force to any woman, intending to outrage or knowing it to be

91. PEN.CODE $\S 375$ (2010) (India).

92. See PEN. Code (2010) (India).

93. LAL, supra note 21. See LAW COMM. OF INDIA, ONE HUNDRED FIFTY-SIXTH REPORT ON THE INDIAN PENAL CODE 184 (1997), available at http://lawcommissionofindia.nic.in/101169/Report 156Voll.pdf [hereinafter 156TH REPORT].

94. VIRANI, supra note 86, at 147.

95. Id.

96. Id.

97. Id.

98. Id. at 137 .

99. PEN. CODE $\S 377$ (2010) (India).

100. BAJPAI, supra note 16, at 219-20.

101. See Child Protection Issues, supra note 10.

102. See id.

103. PEN. CODE $\S 377$ (2010) (India).

104. PEN. CODE $\S 354$ (2010) (India). 
likely that he will thereby outrage her modesty, shall be punished with imprisonment of either description for a term which may extend to two years, or with fine, or with both." 105 Section 354 is alternatively referred to as molestation. ${ }^{106}$ Under Section 354 , only a female's modesty can be outraged; thus, no section of the IPC deals with the sexual molestation of males. ${ }^{107}$

The IPC imposes varying penalties depending on the severity of the crime. However, much like the United States, India rarely imposes the maximum sentence. ${ }^{108}$ For example, in cases of rape, some victims are later married to the abuser, which subsequently results in the charges being dropped. $^{109}$ Even though the maximum prison sentence under Section 377 is ten years, imprisonment terms are most often five years. ${ }^{110}$ Under Section 354, sentences are generally less than the two year maximum term. ${ }^{111}$

The most stringent sexual offense penalties in the IPC are reserved for the crime of rape. Under Section 376, imprisonment ranges from seven years to life. Note that if the victim is a woman, the perpetrator is her husband, and she is 12 years of age or older, the convicted only faces a prison term of up to two years. ${ }^{112}$ In addition to the statutorily-based prison terms, Section 376 allows for significant judicial discretion: the court may, "for adequate and special reasons to be mentioned in the judgment, impose a sentence of imprisonment for a term of less than seven years." "In one example of such latitude, a court reduced a jail term to six months when the rapist agreed to pay the victim's father "four lakh rupees" (Rs. 400,000) following negotiations between the father and the rapist. ${ }^{114}$ The court agreed to the reduction and stated that "the compensation is necessary for a woman who will never get married."115

\section{Goa Children's Act of 2003}

In 2003, Goa, an Indian state, took a major step forward in the fight to reduce CSA with the passage of the Goa Children's Act (GCA). ${ }^{116}$ Many

105. Id.

106. VIRANI, supra note 88, at 137.

107. See Child Protection Issues, supra note 10.

108. See VIRANI, supra note 86, at 137.

109. Id.

110. See Child Protection Issues, supra note 10; VIRANI, supra note 86, at 137.

111. PEN. CODE $\S 354$ (2010) (India).

112. PEN. CODE $\S 376(2010)$ (India).

113. Id.

114. VIRANI, supra note 86, at 137.

115. Id.

116. Goa Children's Act, 2003, No. 18, Act of Leg. Assembly of Goa, 2003 (India), available at http://www.goagovt.nic.in/documents/goachildact2003.pdf. 
child advocates have recommended that this legislation be used as a model to draft a national bill criminalizing incest and CSA in India. ${ }^{117}$ The GCA explicitly criminalized a variety of sexual offenses against children ${ }^{118}$ and set up Children's Courts to try CSA cases. ${ }^{119}$ Under the GCA, CSA is divided into three categories: (1) Grave Sexual Assault, (2) Sexual Assault, and (3) Incest. ${ }^{120}$

According to the GCA, "Grave Sexual Assault . . . covers different types of intercourse: vaginal, oral, anal, use of objects, forcing minors to have sex with each other, deliberately causing injury to the sexual organs, [and] making children pose for pornographic photos or films." ${ }^{21}$ Sexual assault covers "sexual touching with the use of any body part or object, voyeurism, exhibitionism, showing pornographic pictures or films to minors, making children watch others engaged in sexual activity, issuing of threats to sexually abuse a minor, [and] verbally abusing a minor using vulgar and obscene language."122 The GCA is the first Indian statute to explicitly criminalize incest and impose criminal penalties for incest. ${ }^{123}$ Under the GCA, incest is "the commission of a sexual offense by an adult on a child who is a relative or is related by ties of adoption." 124 In addition to the three categories of CSA, the GCA provides a slightly expanded definition of child, which includes all persons under the age of eighteen unless otherwise specified by law. ${ }^{125}$

Depending on the nature and severity of the crime, the GCA provides for both imprisonment and fines. If a person is convicted of grave sexual assault, he or she faces a sentence between seven and ten years, as well as a fine of Rs. $200,000 .^{126}$ A person convicted of sexual assault under the GCA faces a prison sentence of up to three years and a fine of Rs. 100,000. ${ }^{127}$ If

117. See SC Sets Norms to Curb Child Trafficking, Hindustan TIMEs (India), Jan. 16, 2010; Sairam Bhat, Too Little for the Little Ones, INDIA TOGETHER (Dec. 2004), http://www.indiatogether.org/2004/dec/chi-abuse.htm.

118. The GCA does not include CSA in its terminology; instead, the crimes are referred to as sexual offenses. Under the GCA a sexual offense is a sexual act listed in one of the three categories above committed against or with a child. However, for purposes of uniformity in this Note, the term sexual offense (as utilized in the GCA) is analogous to CSA.

119. Goa Children's Act, 2003, § 27. The GCA went into effect in July 2003, and the Children's Court started hearing cases on December 10, 2004. DIRECTORATE OF WOMEN and Child Development (Government of GoA), Citizen's Charter § B (3.4) (2005), available at http://www.goagovt.nic.in/charter/files/women_child/charter.pdf.

120. Goa Children's Act, 2003, §§ 2(y)(i)-(iii).

121. Id. § $2(\mathrm{y})(\mathrm{i})$.

122. Id. § 2(y)(ii).

123. Id. $\S 8(2)$.

124. Id. § $2(\mathrm{y})(\mathrm{iii})$.

125. Id. $\S 2$ (d).

126. Id. § 8(2).

127. Id. 
a person commits incest, he or she faces a maximum imprisonment of one year and a fine of Rs. $100,000 .^{128}$

In addition to creating criminal sanctions for CSA, the GCA created the Children's Court of Goa. ${ }^{129}$ The goal of the Children's Court is to maintain a child-friendly environment that is tailored to the needs of young victims and their parents. ${ }^{130}$ The Children's Court has jurisdiction over all offenses against children, whether specified in the GCA or some other law. ${ }^{131}$ Other than appeals to the Bombay High Court or Indian Supreme Court, no other court has jurisdiction over offenses against children. ${ }^{132}$ All Children's Court proceedings qualify as judicial proceedings. ${ }^{133}$ The Court has the powers of both a civil court and a Court of Sessions under the Code of Criminal Procedure. ${ }^{134}$ This enables the court to issue summons, enforce attendance of witnesses, compel discovery, administer oaths, record evidence, and impose criminal penalties. $^{135}$

The GCA sets out specific procedural safeguards to protect children in Children's Court proceedings. ${ }^{136}$ The Act calls for the use of nonstigmatizing language and explicitly prohibits the use of "adversarial or accusatory words, such as, arrest, remand, accused, charge sheet, trial, prosecution, warrant, summons, conviction, inmate, delinquent, neglected, custody, etc." 137 Furthermore, only a judge may aggressively question a child victim. ${ }^{138}$ In the Children's Court, the accused carries the burden of proof when the victim of the alleged offense is a child. ${ }^{139}$ When a child victim testifies before any authority, including the Court, the child victim may not testify in the presence of the accused. ${ }^{140}$ Instead, provisions provide for testimony by child victims via closed circuit television. ${ }^{141}$ All questions to child victims are to be short, clear, and concise. ${ }^{142}$ Leading questions may be used by social workers when taking the testimony of children under eight years of age. ${ }^{143}$ The GCA also calls for procedures to

128. Id.

129. Id. $\S \S 27-32$.

130. See id. $\$ 27(2)$.

131. Id. $\S 30(1)$.

132. Id. $\S 34$.

133. Id. $\S \S 31(1)-(2)$.

134. $I d$.

135. See id. $\S \S 31(1)-(2), 33$; CODE CrIM. Proc. (2010) (India), available at http://indiacode.nic.in/fullactl .asp?tfnm=197402; PEN. CODE $§ \S 195,228$ (2010) (India).

136. See Goa Children's Act, 2003, No. 18, Act of Leg. Assembly of Goa, 2003, § 32 (India), available at http://www.goagovt.nic.in/documents/goachildact2003.pdf.

137. Id. $\S 32(1)(\mathrm{e})$.

138. Id. $\S 31(2)(\mathrm{e})$.

139. Id. $\S 31(1)(l)$.

140. $I d . \S 31(1)(\mathrm{m})$.

141. Id. $\S 31(2)(\mathrm{f})$.

142. Id. $\S 31(2)(\mathrm{n})(\mathrm{v})$.

143. Id. $\S 31(2)(\mathrm{n})(\mathrm{vi})$. 
increase the child-friendly nature of the Court. Instead of a court proceeding with old English formality, such as robes and wigs, the Court incorporates child friendly apparel, explanations of the roles of court members to young witnesses, informing child witnesses/victims of their role in the proceedings, and enabling children to familiarize themselves with the court surroundings. ${ }^{144}$

The GCA requires the creation of victim assistance units. ${ }^{145}$ These units are designed to assist children in comprehending and healing from CSA. $^{146}$ The victim assistance units also provide support and education to children appearing as witnesses in cases before the Children's Court. ${ }^{147}$ Provisions within the GCA provide for sensitization training for professionals involved in the investigation and litigation of CSA cases. ${ }^{148}$ This training is to combat the lack of experience exhibited by the majority of police, psychologists, doctors, nurses, and other health professionals in India in identifying CSA and helping rehabilitate children from CSA. ${ }^{149}$ Thus, sensitization training is needed to ensure that healthcare and other professionals understand the special needs of child victims in both cases of CSA and child abuse. ${ }^{150}$

Sensitization training should help police and others in law enforcement become familiar with the appropriate laws and rights of children. In order to prosecute and convict CSA offenders, police must be aware of the necessary elements of the crime, the proper procedures, and how to interact with children. Increased convictions are not possible until those involved in the investigative and prosecutorial processes understand both the proper legal basis for prosecution and the needs of the children involved.

However, the GCA has been scrutinized for poor drafting, lack of legal insight, and for placing the responsibility of coping with CSA upon different members of society, such as hotel owners and cyber café operators. ${ }^{151}$ For example, the GCA holds both the owner and the manager of a hotel or similar establishment solely liable for any violations of the GCA. ${ }^{152}$ A hotel owner is required to ensure "that children are safe and not at risk of child abuse within [the hotel's] premises including all adjoining beaches, parks, etc." ${ }^{153}$ Violations include allowing a child to enter a guest

144. Id. §§32(o)(2)(a), 32(2)(n)(i)-(ii), 32(2)(n)(iv), 27(2).

145. Id. $\S 8(19)$.

146. Id.

147. Id.

148. Id. $\S \S 8(20),(21)$.

149. See VIRANI, supra note 86 , at $174-75,185-88$.

150. Id. at 185-86.

151. Bhat, supra note 117.

152. Goa Children's Act, 2003, No. 18, Act of Leg. Assembly of Goa, 2003, § 8(10)(d)

(India), available at http://www.goagovt.nic.in/documents/goachildact2003.pdf.

153. Id. $\S 8(10)(\mathrm{a})$. 
room where he or she is not a registered guest staying with a person related by blood and allowing children access to unfiltered internet facilities. ${ }^{154}$

The constitutionality of the GCA has also been questioned. Lawyers have filed several petitions in the Bombay High Court that question the burden of proof and the access of the accused to cross-examine the child victim aspects of the GCA. ${ }^{155}$ However, none of these petitions have been heard due to the Bombay High Court's case backlog. ${ }^{156}$ Conflicts between the GCA and other laws have also raised concerns. Some argue that provisions of the Indian Constitution and the IPC already protect children from sexual exploitation. ${ }^{157}$ Others argue that the Indian Parliament, which was considering a similar bill when the GCA was passed, should implement this type of legislation. ${ }^{158}$ Critics of the GCA question which act will prevail in the event Parliament does pass similar legislation. ${ }^{159}$

The Children's Court has not been immune from criticism, either. Questions have been raised regarding whether the Children's Court is actually any more child friendly than the other courts in India. ${ }^{160}$ For example, it is unclear whether children must wait for proceedings in the same waiting room as their abusers. ${ }^{161}$ Efforts to observe the court in session have been thwarted. ${ }^{162}$ Furthermore, critics have raised concerns over the speed at which cases are disposed since the court meets only one day a week and requests for additional court days have been ignored. ${ }^{163}$

To deal with criticisms over the GCA, Goa amended the Act in both 2004 and $2005 .^{164}$ The 2005 amendment lowered the age limit for adulthood in cases of rape; currently, a victim of rape is a child if he or she is below the age of sixteen. ${ }^{165}$ Rape is now defined by cross-reference to IPC Section 375 and is classified as a grave sexual assault. ${ }^{166}$ The 2005

154. $I d . \S \S 8(10)(\mathrm{b})-(\mathrm{c})$.

155. See Preetu Nair, Goa Children's Act - A Case Analysis, Sulekha.com (Jan. 2, 2007), http://goadourado.sulekha.com/blog/post/2007/01/goa-childrens-act-a-case-analysis. htm.

156. Id.

157. Id.

158. Id.

159. Id.

160. Id.

161. Id.

162. Id.

163. Id.

164. Goa Children's (Amendment) Act, 2004, No. 12, Act of Leg. Assembly of Goa, 2004 (India), available at http://www.nls.ac.in/ccl/Acts\%20to\%20be\%20loaded The\%20Goa\%20 Childrens\%20Act\%20and\%20Rules.pdf; Goa Children's (Amendment) Act, 2005, No. 20, Act of Leg. Assembly of Goa, 2005, $\S 2$ (d) (India), available at http://www.nls.ac.in/ccl/Acts\%20to\%20be $\% 20$ loaded/The $\% 20$ Goa $\% 20$ Childrens $\% 20$ Act $\% 2$ 0and\%20Rules.pdf.

165. Goa Children's (Amendment) Act, 2005, § 2(d).

166. Id. §§ 2(uv), 2(y)(i). 
amendment also increased fines and prison sentences for both grave sexual assault and incest. ${ }^{167}$ Punishment for grave sexual assault now ranges from ten years to life imprisonment, as opposed to a sentence between seven and ten years. ${ }^{168}$ Punishment for incest convictions was amended to a minimum sentence of ten years and a maximum sentence of life imprisonment. ${ }^{169}$ Incest also carries an increased maximum fine of Rs. 200,000. ${ }^{170}$

The 2005 amendments modified several provisions in order to better protect children involved in cases of CSA. Section 8 now requires a medical examination of the child victim when there are allegations of a grave sexual assault. ${ }^{171}$ In contrast, the 2003 GCA permitted, but did not require, medical examination when grave sexual assault was alleged. ${ }^{172}$ Additionally, several changes were made to Children's Court procedural safeguards. The 2005 amendment altered the burden of proof in cases of offenses against children. ${ }^{173}$ Under the $2003 \mathrm{GCA}$, the burden of proof was placed on the accused if the alleged crime involved a child victim. ${ }^{174}$ The 2005 amendment narrowed the application of this provision so that it applies only to situations where the child victim was in the custody of the accused (1) at the time of his or her arrest, (2) at the time when the offense was committed, or (3) at the time when the child was rescued or removed. ${ }^{175}$ The amendment also modified the procedure for questioning and cross-examining child victims and witnesses. ${ }^{176}$ With the 2005 amendment, child witnesses were entitled to the same procedural safeguards of the GCA as child victims. ${ }^{177}$ Prior to the 2005 amendment, only child victims received special procedural safeguards in order to help reduce psychological distress. ${ }^{178}$ While children are not to testify in the presence of the accused or perpetrators of the alleged crime, the 2005 amendment made an explicit allowance for the presence of the accused's advocate. ${ }^{179}$

167. Id. $\S 8(2)$.

168. Id.

169. Id.

170. Id.

171. Id. $\S 8(3)$.

172. Goa Children's Act, 2003 , No. 18 , Act of Leg. Assembly of Goa, 2003, $\S 8(3)$

(India), available at $\mathrm{http} / / \mathrm{www}$.goagovt.nic.in/documents/goachildact2003.pdf.

173. Goa Children's (Amendment) Act, 2005, No. 20, Act of Leg. Assembly of Goa, 2005, $\S 32(1)(l)$ (India), available at http://www.nls.ac.in/ccl/Acts\%20to\%20be\%20 loaded/The $\% 20$ Goa $\% 20$ Childrens $\% 20$ Act $\% 20$ and\%20Rules.pdf.

174. Goa Children's Act, 2003, § 32(1)(l).

175. Goa Children's (Amendment) Act, 2005, § 32(1)(l).

176. Id. $\S 32(\mathrm{I})(\mathrm{m})$.

177. $I d$.

178. Goa Children's Act, 2003, §32(1)(m).

179. Goa Children's (Amendment) Act, 2005, § 32(1)(m). 


\section{The Commissions for the Protection of Child Rights Act and Amendments}

The Commissions for the Protection of Child Rights Act created national, state, and union territory commissions to protect child rights in every state and union territory in $2005 .^{180}$ The Commissions are directed to examine and review the safeguards provided by law for the protection of child rights. ${ }^{181}$ The Commissions provide recommendations on measures to implement laws effectively in order to best serve the interests of children. ${ }^{182}$ The Commissions study international instruments and treaties to undertake periodic review of all policies, programs, and other activities related to child rights. ${ }^{183}$ In addition, the Commissions make recommendations regarding the effective implementation of international instruments and treaties. ${ }^{184}$ The Commissions' Rules give special focus to assessing India's compliance with the $\mathrm{CRC}$ as well as reviewing and commenting on proposed legislation from a child protection perspective. ${ }^{185}$

The Commissions also have the power to investigate violations of child rights and recommend the initiation of judicial proceedings when necessary. ${ }^{186}$ When either a child or a person concerned on the child's behalf makes a complaint, the Commission may initiate a formal investigation. ${ }^{187}$ A Commission, when undertaking a formal investigation, has the same powers as a civil court trying a suit under the 1908 Code of Civil Procedure. ${ }^{188}$ This enables the Commissions to summon and enforce the attendance of any person and require discovery and/or document production. $^{189}$

The Commissions for Protection of Child Rights Act also created

180. Commissions for Protection of Child Rights Act, No. 4 of 2006, $\S 3$, INDIA CoDE (2010), available at http://www.ncpcr.gov.in/Acts/National_Commission_for_Protection_ of_Child_Rights_Act_2005.pdf.

181. $\overline{I d} . \S \S 13(1)(\overline{\mathrm{a}}), 17(1)$.

182. Id. $\S \S 13(1)(\mathrm{a}), 13(\mathrm{f}), 24(\mathrm{a})-(\mathrm{b})$.

183. Id. $\S \S 13(1)(\mathrm{c}), 24(\mathrm{a})-(\mathrm{b})$.

184. Id. $\$ \S 13(1)(\mathrm{f}), 24(\mathrm{a})-(\mathrm{b})$.

185. Commissions for Protection of Child Rights Rules, 2006, $\S 17(a)$, Gazette of India, part II, section 3(i), (July 31, 2006), available at http://www.ncpcr.gov.in/Acts/National_ Commission_for_Protection_of_Child_Rights_NCPCR_Rules.pdf.

186. Commissions for Protection of Child Rights Act, No. 4 of $2006, \S \S 13(1)(\mathrm{c}), 24(\mathrm{a})$ (b), INDIA CODE (2010), available at http://www.ncpcr.gov.in/Acts/National_Commission_ for_Protection_of_Child_Rights_Act_2005.pdf.

187. Commissions for Protection of Child Rights Rules, 2006, $\S 17(\mathrm{c})$, Gazette of India, part II, section 3(i), (July 31, 2006), available at http://www.ncpcr.gov.in/Acts/National_ Commission_for_Protection_of_Child_Rights_NCPCR_Rules.pdf.

188. Commissions for Protection of Child Rights Act, No. 4 of 2006, $\S \S 14(1), 24(\mathrm{a})-(\mathrm{b})$, INDIA CODE (2010), available at http://www.ncpcr.gov.in/Acts/National_Commission for_Protection_of_Child_Rights_Act_2005.pdf.

189. Id. $\S \overline{14}(\overline{\mathrm{l}})(\mathrm{a})-(\mathrm{e}), 24(\mathrm{a})-(\mathrm{b})$. 
children's courts for the speedy trial of offenses against children and violations of children's rights. ${ }^{190}$ The state or union territory government may appoint a special prosecutor or advocate for the purpose of conducting cases in the Children's Court. ${ }^{191}$

While the Commissions were an important step toward protecting the rights of children, the Commissions have not addressed CSA, electing to focus instead on corporal punishment, juvenile justice, child labor, and education. ${ }^{192}$ Moreover, the National Commission neither has a CSA working group nor specifically addresses CSA concerns. ${ }^{193}$ The National Commission does not concern itself with CSA because the Commissions for the Protection of Child Rights Act focus on children affected by terrorism, natural disaster, domestic violence, HIV/AIDS, trafficking, children in conflict with the law, and increasing child literacy. ${ }^{194}$

\section{Other Acts}

Several other acts strive to protect children from CSA. These acts include the Juvenile Justice Act, ${ }^{195}$ the Juvenile Justice (Care and Protection of Children) Act, ${ }^{196}$ the Juvenile Justice (Care and Protection of Children) Amendment Act, ${ }^{197}$ the Prevention of Immoral Traffic Act, ${ }^{198}$ and the Prohibition of Child Marriages Act. ${ }^{199}$ The 1986 Juvenile Justice Act does not directly deal with CSA; instead, it primarily deals with the care, protection, treatment, development, and rehabilitation of delinquent and neglected children. ${ }^{200}$ Specifically, the Act created Juvenile Justice Boards

190. Id. § 25 .

191. Id. § 26 .

192. See Issues, NAT'L COMM. FOR THE Protection OF CHILd Rights, http://www.ncpcr.gov.in/issues.htm (last visited Dec. 22, 2010).

193. The current working groups include: Child Labor and Education; Juvenile Justice; Corporal Punishment; Child Health and Nutrition; Female Foeticide; Children without Parental Care; Child Participation in TV/Reality Shows; Safeguards for Children on Railway Platforms; International Displaced Children; and Child Rights and Panchayats. See NCPCR Working Groups, NAT'L COMM. FOR THE PROTECTION OF CHILD RIGHTS, http://www.ncpcr.gov.in/ working_groups.htm (last visited Dec. 22, 2010).

194. Commissions for Protection of Child Rights Act, §§ 13(1)(d)-(e), 24(a)-(b).

195. Juvenile Justice Act, 1986, No. 53 of 1986, repealed by Juvenile Justice (Care and Protection of Children) Act, 2000, No. 56 of 2000, INDIA CODE (2010).

196. Juvenile Justice (Care and Protection of Children) Act, 2000.

197. Juvenile Justice (Care and Protection of Children) Amendment Act, 2006, No. 33 of 2006, INDIA CODE (2010), available at http://wcd.nic.in/childprot/jjactamedment.pdf.

198. Prevention of Immoral Traffic Act, 1986, No. 44 of 1986, INDIA CODE 2010 (amending Suppression of Immoral Traffic in Women and Girls Act, 1954, No. 58 of 1954).

199. Prohibition of Child Marriage Act, 2007, No. 6 of 2007, InDiA CODE (2010), available at http://wcd.nic.in/cma2006.pdf.

200. Juvenile Justice Act, 1986, pmbl., No. 53 of 1986, repealed by Juvenile Justice (Care and Protection of Children) Act, 2000, No. 56 of 2000, INDIA CODE (2010). 
to deal with accusations of neglect and delinquency. ${ }^{201}$ These boards were not created to deal with CSA victims, and no specialized care or treatment was provided for CSA victims. ${ }^{202}$

The 1986 Juvenile Justice Act was the primary legal framework for juvenile justice in India until the passage of the Juvenile Justice (Care and Protection of Children) Act in 2000, which replaced the Juvenile Justice Act. ${ }^{203}$ The Juvenile Justice (Care and Protection of Children) Act contained substantial modifications and changes in terminology, including the replacement of Juvenile Welfare Boards with Child Welfare Committees. ${ }^{204}$ Section 23 of the Juvenile Justice (Care and Protection of Children) Act addressed cruelty to a child, stating that when a person who has control of or otherwise is in charge of a child assaults the child, or procures a child to be assaulted in a manner likely to cause unnecessary mental or physical suffering, that controlling person may be punished with imprisonment up to six months and/or a fine. ${ }^{205}$ However, this Act does not directly address CSA or the special needs of CSA victims. ${ }^{206}$

The Juvenile Justice (Care and Protection) Act was amended in $2006{ }^{207}$ The 2006 Amendments ordered each state to create a Child Protection Unit to address the needs of children who have had prior unlawful encounters and to address the needs of children in group homes. ${ }^{208}$ These units are not trained to deal with CSA or sexual offenses. ${ }^{209}$

The 2006 Amendments also attempted to reduce the length of time that it takes the Boards to resolve cases. ${ }^{210}$ According to the Juvenile Justice (Care and Protection) Act, cases in front of the Welfare Boards were to be resolved within four months. ${ }^{211}$ However, that portion of the statute lacked proper implementation. ${ }^{212}$ So, in 2006 Parliament instructed the Chief Magistrate to review the pendency of cases every six months. The Chief Magistrate has the ability to order additional sittings of the Welfare Boards or to create additional Boards, depending on the backlog. ${ }^{213}$

201. Id. $\S 4$.

202. BAJPAI, supra note 16, at 217.

203. Juvenile Justice (Care and Protection of Children) Act, 2000, §69.

204. Id. § 29.

205. Id. § 23.

206. See BAJPAI, supra note 16 , at 217.

207. Juvenile Justice (Care and Protection of Children) Amendment Act, 2006, No. 33 of 2006, INDIA CODE (2010), available at $\mathrm{http}: / / \mathrm{wcd} . \mathrm{nic} . \mathrm{in} / \mathrm{cma2006}$.pdf.

208. Id. § 24.

209. See BAJPAl, supra note 16, at 217.

210. Juvenile Justice (Care and Protection of Children) Act, No. 56 of 2000, $\S 14$; INDIA CODE (2010), available at $\mathrm{http}: / /$ nicp.nisd.gov.in/pdf/jjact.pdf.

211. Id.

212. KACKER ET AL., supra note 8, at 27.

213. Juvenile Justice (Care and Protection of Children) Amendment Act, No. 33 of 2006, $\S 11(2)$; INDIA CODE (2010), available at http://wcd.nic.in/childprot/jjactamedment.pdf. 
The 1986 Immoral Trafficking Prevention Act primarily punishes the acts of third parties that facilitate prostitution and sex trafficking, such as brothel keepers and pimps. ${ }^{214}$ However, punishing brothel keepers and pimps neither provides comprehensive protection for children nor specifically addresses CSA. Finally, the government enacted the Prohibition of Child Marriages Act 2006 in order to prevent the solemnization of child marriages, but this Act also fails to address CSA. ${ }^{215}$

\section{Case Law - Sakshiv. Union of India \& Ors}

In 1997, Sakshi, a well-respected non-governmental organization (NGO) interested in issues concerning women and children, ${ }^{216}$ brought CSA to the attention of the Supreme Court of India. ${ }^{217}$ Sakshi petitioned the court to declare that rape under IPC Section 375 included all forms of forcible penetration, instead of being limited to penile penetration. ${ }^{218}$ Sakshi argued that the definition of rape under Section 375 violated both the Indian Constitution and India's commitments under international agreements such as the CRC and the United Nations Convention on the Elimination of all Forms of Discrimination Against Women. ${ }^{219}$ On January 13, 1998, the Supreme Court of India directed the Law Commission of India to address the issues raised in Sakshi's writ petition regarding the reach of penetration under Section $375 .{ }^{220}$

On July 28, 1998, the Law Commission filed an affidavit setting out portions which dealt with the issues raised by Saksh ${ }^{221}$ in its 156th Report on the Indian Penal Code. ${ }^{222}$ The 156th Report did not agree with Sakshi's position. ${ }^{223}$ Sakshi submitted a response to the Court arguing that the 156th Report did not deal with the precise issues raised in its writ petition. ${ }^{224}$ The Court directed Sakshi to write a note concerning the precise issues involved in the petition. ${ }^{225}$ Following Sakshi's note submission, on August 9, 1999, the Court ordered the Law Commission of India to examine the precise

214. Prevention of Immoral Traffic Act, 1986, No. 44 of 1986, INDIA CODE 2010 (amending Suppression of Immoral Traffic in Women and Girls Act, 1954, No. 58 of 1954).

215. Prohibition of Child Marriage Act, 2007, pmbl., No. 6 of 2007, IndiA CODE (2010).

216. Sakshi v. Union of India \& Ors, (1999) 6 S.C.C. 591 (India).

217. Id.

218. Shri Ram Jethmalani, Introduction to LAW COMM. OF INDIA, ONE HundRED AND SEVENTY SECOND REPORT ON REVIEW OF RAPE LAWS (2000), available at http://www.lawcommissionofindia.nic.in/rapelaws.htm.

219. Id.

220. Id.

221. See id.

222. 156TH REPORT, supra note 93.

223. Id.

224. Id.

225. Id. 
issues submitted by Sakshi. ${ }^{226}$ The Court specifically requested that the Law Commission "examine the issues submitted by [Sakshi] and examine the feasibility of making recommendations for amendment of the [IPC] or deal with the same in any other manner so as to plug the loopholes."227

Pursuant to the Court's order, the Law Commission of India reviewed the IPC rape laws and recommended amending certain sections, including Sections 375, 376, and $377 .^{228}$ The Law Commission also made recommendations for amendments to the Code of Criminal Procedure ${ }^{229}$ and the Indian Evidence Act. ${ }^{230}$ The Law Commission found that, in light of increased reports of custodial rape and CSA, the IPC needs to be amended to adopt a modern understanding of sexual offenses and include more stringent penalties. ${ }^{231}$

\section{RECOMMENDATIONS}

\section{A. Gaps in the Current System}

Most existing child protection mechanisms under Indian laws cater to post-harm situations. ${ }^{232}$ Preventative measures are wholly lacking in India's approach to child protection. ${ }^{233}$ In fact, preventative child protection has never been a part of India's child protection plan. ${ }^{234}$ Additionally, glaring gaps exist in India's infrastructure and outreach services for children. These gaps include: (1) poor planning and coordination, (2) lack of sufficient coverage for India's children, and (3) poor infrastructure. ${ }^{235}$ A poor understanding of child rights and a lack of a child-friendly approach has affected both planning and service delivery and has resulted in these gaps. ${ }^{236}$

Currently, child protection schemes are spread throughout various ministries and departments. For example, the Labor Ministry is responsible for child labor elimination; the Ministry of Women and Child Development is responsible for juvenile justice, child trafficking, and adoption-related

226. Id.

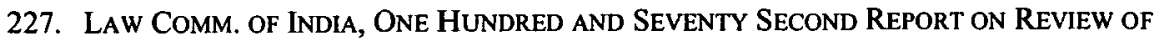
RAPE LAWS (2000), available at http://www.lawcommissionofindia.nic.in/rapelaws.htm [hereinafter 172ND REPORT].

228. Id.

229. CODE CRIM. Proc. (2010) (India), available at http://indiacode.nic.in/ fullactl .asp?tfnm=197402; PEN. CODE $\S \S 195,228$ (2010) (India).

230. Indian Evidence Act, No. 1 of 1872, INDIA CODE (2010); 172ND REPORT, supra note 233.

231. 172ND REPORT, supra note 227.

232. KACKER ET AL., supra note 8, at 31.

233. Id.

234. Id.

235. Id.

236. See id. at 6. 
matters; and the Ministry of Health and Family Welfare is responsible for the implementation of the Pre-Conception and Pre-Natal Diagnostic Techniques (Prohibition of Sex Selection) Act. ${ }^{237}$ Therefore, India's ability to undertake preventative measures for child violence, child abuse, and other harms to children is limited by a severe lack of communication and cooperation among various National and State Ministries and Departments. $^{238}$

India has inadequate child protection resources. ${ }^{239}$ The 1974 National Policy for Children declared children to be a "supreme national asset."240 To this end, the Policy pledged to secure and safeguard children's needs by making wise use of available national resources. ${ }^{241}$ Unfortunately, ten successive Five Year Plans have failed to allocate adequate resources to meet the needs of children. ${ }^{242}$ A study by the Ministry of Women and Child Development revealed that combined total expenditures on children in 2005-2006 for health, education, development, and protection amounted to a mere 3.86 percent of India's total expenditures. ${ }^{243}$ This figure rose to 4.91 percent in 2006-2007. ${ }^{244}$ However, the share of resources allocated for expenditures on children used specifically for child protection was abysmally low at 0.034 percent in 2005-2006 and remained unchanged in 2006-2007..$^{245}$ Available resources have not been utilized effectively protecting the innocence of India's children. ${ }^{246}$

India's current infrastructure also lacks sufficient coverage of India's children. ${ }^{247}$ The number of children with no support or services is everincreasing. ${ }^{248}$ Further compounding this issue is the lack of systematic and comprehensive mapping (1) of children in need of services or (2) of the services available for children on a local and national scale. ${ }^{249}$ Additionally, India's minimal infrastructure is rigid, and a significant amount of resources are spent maintaining the structure rather than focusing on outcomes. ${ }^{250}$ Furthermore, a great deal of the infrastructure required by various acts has not been implemented, including Juvenile Justice Boards

237. Id. at 31 .

238. Id.

239. Id. at 6 .

240. Id.

241. Id.

242. Id.

243. Id.

244. Id.

245. Id.

246. Id.

247. Id. at 31 .

248. Id.

249. Id.

250. Id. 
and Child Welfare Committees. ${ }^{251}$ Finally, shelters and institutional care facilities for children in need of services are highly inadequate. ${ }^{252}$

Therefore, based on India's poor planning and coordination of child services, lack of sufficient coverage for India's children, and poor child service infrastructure, serious gaps exist in services for India's children. Due to the fragmented structure of India's child protection plan, no services deal with all categories of child protection. Thus, monitoring of the existing fragmented programs is fairly poor, which further reflects that child protection is not a priority in the Indian States and Union Territories. ${ }^{253}$

The lack of funding and service gaps must be addressed in conjunction with any legislative or executive changes. Proper funding of India's child protection programs will allow the government to effectively address problem areas that currently jeopardize India's compliance with the $\mathrm{CRC}$. India has a responsibility to its children to provide adequate funding for both its existing and any new CSA programs.

\section{B. Legislative Changes}

In order to explicitly denounce CSA and decrease the number of CSA incidents, Parliament should: (1) adopt a national law criminalizing CSA and incest, (2) revise the IPC to reflect the current understanding of sexual offenses such as rape, and (3) encourage States to pass laws criminalizing CSA and incest.

India must adopt a national law that explicitly criminalizes CSA and incest. The GCA can serve as a model to develop the new law. By explicitly stating that CSA is not acceptable, India will perform both a signaling and channeling function regarding acceptable behavior toward children. While all countries struggle to address CSA, India is one of the few nations that does not explicitly criminalize CSA. ${ }^{254}$ Under the CRC, India is required to take "appropriate legislative, administrative, social and educational measures" to protect children from CSA and incest. ${ }^{255}$ However, India's high rate of CSA shows that India's current laws do not appropriately address CSA. ${ }^{256}$ Furthermore, the nature of the current IPC makes CSA prosecution and conviction difficult. ${ }^{257}$ Because most abusers believe that they will likely not be caught, and even if they are caught, the case may not be tried for years, it is unlikely that an explicit law

251. Id.

252. Id.

253. See id.

254. See Sara Shapouri, Ending Child Sexual Abuse and Exploitation: A Guide for Child

Protection in Iran, 7 WHITTIER J. CHILD \& FAM. ADVOC. 63, 92 (2007).

255. Convention on the Rights of the Child, supra note 5, art. 19.

256. See supra Part I.

257. See VIRANI, supra note 86 , at 90-91, 141, 181-82. 
criminalizing CSA will deter such abusive behavior. ${ }^{258}$ While an explicit law on its own will not be a complete deterrent from criminal activity for most abusers, this law will provide both police and social workers with tools to develop and try cases against abusers. An explicit CSA law will also enable India to better comply with the child protection requirements of the CRC.

A national law criminalizing CSA and incest should include the following provisions to protect child victims and increase the number of successful CSA prosecutions: (1) remove the presumption of innocence for child guardian(s), ${ }^{259}(2)$ incorporate procedures to protect child witnesses, ${ }^{260}$ (3) incorporate procedures and rules to make courts child-friendly, ${ }^{261}$ (4) incorporate procedures to reduce the length of litigation, (5) create a child protective services agency to investigate allegations of CSA and incest, $^{262}$ and (6) create a reporting system mandating the reporting mechanisms and persons responsible for reporting CSA. ${ }^{263}$

First, under the current system, there is a presumption that a child's guardian(s) are innocent. ${ }^{264}$ Therefore, a prosecuting lawyer must overcome this presumption in trying cases against parents, uncles, and others who live with the child. This takes incredible commitment on the part of the lawyer since courts do not generally side with the prosecution. ${ }^{265}$ To protect Indian children against CSA, the presumption of guardian innocence must be overturned.

Second, procedures need to be implemented in order to ensure the protection of child witnesses in CSA cases. In Sakshi, the Supreme Court of India approved the use of a screen while in court to shield a victim from view of or by the accuser. ${ }^{266}$ In addition to screen usage, other procedures could be implemented, including the using closed circuit television examinations, questioning of child witnesses by a judge, and using a child's deposition in lieu of live testimony. ${ }^{267}$

The GCA also provides many specific examples of measures other than screens to protect child witnesses. Like the GCA, any new CSA law should require the use of non-stigmatizing language and prohibit the use of "adversarial or accusatory words, such as, arrest, remand, accused, charge sheet, trial, prosecution, warrant, summons, conviction, inmate, delinquent,

258. See Shapouri, supra note 254 , at 88 . But see SMALLBONE ET AL., supra note 32 , at 94, 97-104.

259. BAJPAl, supra note 16, at 262.

260. Id. at 242-44.

261. VIRANI, supra note 86, at 156-57.

262. Id. at 180-88. BAJPAI, supra note 16 , at 241.

263. KACKER ET AL., supra note 8, at 121.

264. BAJPAI, supra note 16 , at 262.

265. See id.

266. Sakshi v. Union of India \& Ors, A.I.R. 2004 S.C. 3566 (India).

267. BAJPAI, supra note 16, at 243-44. See 18 U.S.C. $\$ 3509$ (b). 
neglected, custody, etc."268 Aggressive questioning of a child victim should be permitted only if done by the judge. ${ }^{269}$ All questions should be asked in child-friendly language, which is short, clear, and concise. ${ }^{270}$ Ideally, when a child victim testifies before any authority, including the court, the child victim should not testify in the presence of the accused or the alleged perpetrators. ${ }^{271}$ "In camera proceedings" are provided for under Section 327(2) of the Code of Criminal Procedure for trials of rape under IPC Section $376 .{ }^{272}$ Sakshi expanded this section to apply to trials under IPC Sections 354 and $377 .{ }^{273}$ However, in camera proceedings should be extended to apply in all cases of child abuse under the new national law.

Additionally, in the United States and United Kingdom, a child witness can be accompanied by an adult of the child's choosing at a judicial proceeding. ${ }^{274}$ In CSA cases, this person could be someone the child feels comfortable with, such as the non-abusing parent and/or a close family friend. ${ }^{275}$ Therefore, because of the child's comfort with the adult, this adult could be extremely effective in helping a child cope with trial. Furthermore, a child should be allowed to bring a comfort object to the stand such as a blanket, toy, or doll. ${ }^{276}$ In order to make the courts childfriendly, India should follow the lead of the United States and United Kingdom and allow children to have a trusted adult and a familiar object with them at trial.

Third, similar to protecting child witnesses, any new CSA law should require courts to adopt child-friendly procedures in CSA cases. Under the 2005 Commissions for the Rights of the Child, Children's Courts were established ${ }^{277}$ These courts are likely the best venue to hear CSA cases due to their focus on children's cases; however, in order to be the best venue, the judges and staff must be provided with specialized training in how to avoid secondary victimization of CSA victims. Since not all Indians are fluent in English, ${ }^{278}$ interpreters should be provided, when necessary, to

268. Goa Children's Act, 2003, No. 18, Act of Leg. Assembly of Goa, 2003, § 32(1)(e) (India), available at http://www.goagovt.nic.in/documents/goachildact2003.pdf.

269. Id. $\S 32(2)(\mathrm{e})$.

270. Id. $\S 32(2)(\mathrm{n})(\mathrm{v})$.

271. Id. §32(1)(m).

272. CODE CRIM. PROC. § 327(2) (2010) (India), available at http://indiacode.nic.in/ fullactl.asp?tfnm=197402.

273. Sakshi v. Union of India \& Ors, A.I.R. 2004 S.C. 3566 (India).

274. 18 U.S.C. $\$ 3509(\mathrm{i})$.

275. BAJPAI, supra note 16 , at 246.

276. Id.

277. Commissions for Protection of Child Rights Act, No. 4 of 2006, § 3, INDIA CODE (2010), available at http://www.ncpcr.gov.in/Acts/National_Commission_for_Protection_ of_Child_Rights_Act_2005.pdf.

278. India: People, Cent. InTElligence AgenCY - THE World FactBoOK, https://www.cia.gov/library/publications/the-world-factbook/geos/in.html (last visited Jan. 22, 2011). 
allow the child to communicate in a comfortable and effective manner.

Fourth, to be more child-friendly, any new CSA law should reduce the length of litigation by requiring the speedy resolution of CSA cases. Currently, delays at every stage in the process of investigation and prosecution prevent CSA victims from beginning the healing process. ${ }^{279}$ In several cases, CSA victims reach adulthood prior to the conclusion of the hearing for their case. ${ }^{280}$ Therefore, cases must be tried in a timely manner. In order to speed the trial process, courts must meet more frequently, and additional courts must be established.

Fifth, the core of any CSA law should be a child protection unit that includes specialized CSA investigators. While the GCA called for Victim Assistance Units, the child protection units called for in this Note are more robust and require the establishment of an agency that both investigates and prosecutes CSA and other types of child abuse/neglect cases in order to put India on par with other Western countries' protection of CSA victims, such as the United States and the United Kingdom. ${ }^{281}$

In the United States, each state determines its own CSA scheme, but most utilize an executive agency, such as Child Protective Services in Indiana, that investigates and tries cases of child abuse. ${ }^{282}$ England and Wales established inter-agency cooperation systems. ${ }^{283}$ Overall responsibility for child protection in England and Wales rests with the Department for Children, Schools, and Families, which issues statutory and non-statutory guidance to local authorities. ${ }^{284}$ Reports are made either directly to local authorities or to the National Society for the Prevention of Cruelty to Children, which then passes reports to local authorities. ${ }^{285}$ Additionally, social workers trained in meeting the needs of child victims conduct investigations. ${ }^{286}$ As in the United States, if a child is in imminent danger, police in England and Wales take immediate action to remove the child. $^{287}$ Similar systems are in place in Scotland and Ireland. ${ }^{288}$

In the Netherlands, the Dutch Child Protections Board under the Ministry of Justice conducts investigations. ${ }^{289}$ The Child Protection Board

279. BAJPAI, supra note 16, at 226. See 18 U.S.C. $\$ 3509$ (j).

280. BAJPAI, supra note 16 , at 226.

281. Id. at 242 .

282. See id. at 241; Child Protective Services, IND. DEPT. ChILD SERvs., http://www.in.gov/dcs/2398.htm (last visited Dec. 22, 2010).

283. Helen Walters, Natl. Soc'y for the Prevention of Cruelty to ChlddRen, ChiLd PROTECTION FACTSHEET 3 (2008), available at http://www.nspcc.org.uk/ Inform/research/ questions/child_protection_system_wdf76008.pdf.

284. Id.

285. Id. at 13.

286. Id.

287. Id.

288. Id. at 3.

289. BAJPAI, supra note 16, at 241. 
is a specialized agency that receives reports from schools, agencies, doctors, police, and other interested persons. ${ }^{290}$ The Board uses social workers to investigate children's rights violations and takes necessary steps to protect the child from future abuse. ${ }^{291}$

Child protection units in India should be comprised of specialized staff sensitive to the needs of CSA victims that performs investigations, prosecutions, and pre/post-family services. The staff should include both males and females in order to make children as comfortable as possible during the investigation. As far as possible, the staff member originally assigned to the child's case should stay with the case until completion. Additionally, the staff should be attired in plain clothes, rather than a uniform, to increase the child's comfort. ${ }^{292}$ The staff should be fluent in the languages spoken in the region that the agency serves. The staff should also be fluent in English, the language of India's court system. ${ }^{293}$ The staff should also be educated beyond the tenth standard, ${ }^{294}$ so that they can interact with both educated and uneducated members of society. ${ }^{295}$ In short, comprehensive child protection units would be a big step forward in providing the necessary infrastructure to address CSA properly in India.

Sixth, India must (1) develop a national CSA reporting system and (2) determine if suspected CSA must be mandatorily reported. Currently, India has no mandatory reporting of any type of suspected child abuse. ${ }^{296}$ In contrast, both the United States and United Kingdom have adopted mandatory reporting laws that require mandated reporters to report suspected cases of child abuse. ${ }^{297}$ Who qualifies as a mandated reporter varies by jurisdiction. ${ }^{298}$ Some jurisdictions require all persons to report suspected CSA cases while others require only doctors to report. ${ }^{299}$

The merits of mandatory CSA reporting are not without question. Some believe that mandatory CSA reporting has caused greater public awareness of the problem of child abuse through professional alertness and

290. Id.

291. Id.

292. See VIRANI, supra note 86, at 156.

293. Id. at 185 .

294. Id. The tenth standard is roughly equivalent to the tenth grade. For more information regarding the structure of India's education system, please see http://www.indianetzone.com/ 39/structure_indian_education.htm for more information regarding the structure of India's education system.

295. Id.

296. BAJPAI, supra note 16 , at 242.

297. VIRANI, supra note 86 , at 184.

298. Paul S. Appelbaum, Law \& Psychiatry: Child Abuse Reporting Laws: Time for Reform?, 50 PSYCHIATRIC SERVICES 27, 27-29 (1999), available at http://psychservices.psychiatryonline.org/cgi/content/full/50/1/27.

299. Id. 
intervention. $^{300}$ However, others believe that mandated reporting leads to underreporting and inappropriate reporting. ${ }^{301}$ Belgium, the Netherlands, and Luxembourg have adopted an alternate form of reporting in which a doctor within the health care system acts as a "confidential doctor." ${ }^{\text {, }}$ "This doctor receives all allegations regarding child maltreatment. ${ }^{303}$ Once an allegation is made through a report, the confidential doctor initiates a confidential investigation without threat of immediate coercive intervention. $^{304}$

The implementation of either mandatory CSA reporting system in India would promote the discovery of CSA and provide statistical data about CSA. This data would enable India to track instances of CSA better and eventually create a database of known abusers. In turn, this information would also better enable police and social workers to perform investigations and outreach services to CSA victims.

\section{Executive Changes}

The Executive branch should implement the following four changes to decrease incidents of CSA: (1) increase training for professionals in the identification of CSA in children, (2) increase community education regarding CSA, (3) increase CSA arrests and prosecutions, and (4) create outreach and support services for CSA victims.

First, most of India's doctors, psychologists, and nurses have never received formal CSA training. ${ }^{305}$ As of 2000 , India was without any college or university medical or mental health courses on assisting victims of CSA. $^{306}$ Those who work with child victims are either self-taught or have received training from other professionals working with CSA victims. ${ }^{307}$ Currently, doctors faced with clear physical signs of sexual abuse often refuse to identify it as CSA. ${ }^{308}$ Doctor's notations include "simple injury,' 'patient's promiscuity,' 'congenital problem of absence of hymen,' [and] 'consequence of excessive masturbation.",309 In many cases, medical reports are also vague and incomplete, with no mention of the trauma

300. Id.

301. Anita Lichma, Mandatory Reporting for Child Abuse: A Need for Clarification, ESSORTMENT, http://www.essortment.com/all/mandatoryreport_rcfl.htm (last visited Dec. 22, 2010). See also Appelbaum, supra note 298, at 27-29.

302. VIRANI, supra note 86, at 184.

303. Appelbaum, supra note 298 , at 27-29.

304. Id.

305. See BAJPAI, supra note 16 , at 215.

306. VIRANI, supra note 86 , at 174-75.

307. Id.

308. Id. at 44.

309. Id. See also BAJPAI, supra note 16, at 226. 
caused to the victim. ${ }^{310}$ Therefore, to identify and treat potential CSA victims effectively, doctors must have the opportunity for specialized CSA training and sensitization.

Police also do not receive training in how to identify and/or interact with CSA victims. ${ }^{311}$ To combat problems in identifying and interacting with CSA victims, India should train its existing police force in CSA matters and/or set up specially-trained child protection units. As stated above, the creation of an agency empowered to investigate child abuse has been successful for several countries. ${ }^{312}$ A CSA-focused agency in India would allow for the specialized training of investigators, which can also provide training in child sensitization for local police departments and village gram panchayats. ${ }^{313}$

India should work with other countries to start training programs that teach people who deal with CSA how to investigate and identify CSA and other forms of abuse. For example, India could have a team of experts from the United States and United Kingdom train a group of master trainers in India's Ministry of Women and Child Development. These master trainers could then provide training in connection with the State Commissions on Child Rights to create training teams in each State and Union Territory. A single team of master trainers should include at least one physician, one psychologist, and one police officer (active or retired) in order to connect with their trainees by having all CSA-related professions represented and to adapt the training to India's society and culture.

Second, India must increase community education and awareness of CSA and its effects. ${ }^{314}$ The United States has utilized a variety of education programs to alert children to CSA including "stranger danger," "good touch/bad touch," and basic sex education. ${ }^{315}$ While "stranger danger" programs perpetuate the myth that only strangers perpetrate CSA, the "good touch/bad touch" programs can reach more forms of CSA. These programs could be adapted to an Indian audience and include different languages to help children learn techniques for protecting their bodies. In the United States, most programming is aimed at elementary-aged children (ages five

310. BAJPAI, supra note 16 , at 215.

311. Id.

312. See id. at $241-42$.

313. Gram panchayats are the local governments at the village level in India.

314. See VIRANI, supra note 86 , at xxvii-xxx.

315. See Ernest E. Allen, Keeping Children Safe: Rhetoric and Reality, 5 JUVENILE JUSTICE J. (1998) available at http://www.ojjdp.gov/jjjournal/jjjournal598/safe.html; Good Touch, Bad Touch, CHILDHELP, http://www.goodtouchbadtouch.com/gtbt (last visited Jan. 22, 2011); Children's Programs at the YMCA, YMCA OMAHA, http://www.ywcaomaha.org/ SchoolBasedPrograms.aspx (last visited Jan. 22, 2011). 
to twelve). ${ }^{316}$ India could target a similar age range. This would allow India to reach the largest number of students since schooling is provided for all Indians through age fourteen.

Additionally, community outreach programs should target adults. Parents hold the ultimate responsibility for protecting their children. Therefore, parents must not only be provided with the tools to talk to their children about CSA, but also must learn the signs of CSA. State Commissions on Child Rights or local NGOs could provide such programs. Multiple mediums, including television, Internet, billboards, pamphlets, and workshops can raise awareness. Experimentation with multiple forms of outreach and mass media will be necessary to find the methods that work best in each Indian locale.

Third, and perhaps most important to curtail CSA, India must make a concerted effort to increase arrests and prosecutions of child sexual abusers. If the IPC is modernized and other changes recommended in this Note are implemented, police and/or social workers will be better equipped to build cases against abusers. Currently, CSA investigations are low-priority, peripheral crimes for police. ${ }^{317}$ This must be rectified. While police can investigate only CSA incidents that are reported to them, police often fail to properly investigate incidents that are reported. ${ }^{318}$

Fourth, India must set up outreach and support services for victims of CSA. NGOs and government agencies could work together to provide counseling, education, and family support services. Child victims of CSA often require specially trained mental health professionals and family support services to enable children to rebound from CSA. ${ }^{319}$

\section{CONCLUSIONS}

Children are the most valuable asset of any country. They are the future of any country and of the global community. Over the past two decades, India has realized that CSA is not just a Western phenomenon - it is a human phenomenon. ${ }^{320}$ It does not happen only to "those people," but it happens to all people, including rich, poor, educated, and uneducated. Fifty-three percent of India's children have been victims of CSA. ${ }^{321}$ While India has traditionally blamed those involved in child prostitution and

316. Prevent Child Sexual Abuse America, Preventing Child Sexual Abuse 2 (2005) available at http://www.preventchildabuse.org/advocacy/downloads/child_ sexual_abuse.pdf.

317. BAJPAI, supra note 16 , at $215,263$.

318. VIRANI, supra note 86, at 155-56.

319. See Understanding Child Sexual Abuse: Education, Prevention, and Recovery, AMERICAN PSYCHOLOGICAL Ass'N, http://www.apa.org/pubs/info/brochures/sex-abuse.aspx (last visited Jan. 22, 2011). See also VIRANI, supra note 86, at 174-76.

320. See supra Part I.

321. Id. 
trafficking for the high instances of CSA, studies have shown that the majority of abuse is perpetrated by those known to the victim. ${ }^{322}$ Even though India has made several steps in the right direction to reduce CSA, further action is required. India must signal to its people and the world that CSA is a serious crime against children and will not be tolerated.

First, India must revamp its legal system to deal with a modern understanding of both sexuality and sexual violence. The Indian Penal Code must be modernized to make CSA an explicit crime. A modern and explicit penal structure would channel other changes that are necessary to protect children, such as lifting the veil of secrecy surrounding sensitive issues such as CSA.

The United States underwent a significant transformation of its CSA laws in the 1960s and 70s. ${ }^{323}$ Though not perfect, the United States, has made significant progress in protecting children from CSA and other forms of abuse. For example, CSA is investigated by agencies with specialized training, treated by doctors who are trained to identify CSA, and reported under a mandatory CSA reporting system. ${ }^{324}$ Additionally, children are educated about CSA through television shows and school-sponsored programs. ${ }^{325}$ While programs in the United States and other nations, such as Great Britain, may not be a perfect fit for India, these programs provide a template for India to develop methods of protection from CSA.

Finally, India will not be able to fix CSA overnight. Cultural and social mindsets must change. Changing deeply ingrained social norms will not be a quick or easy process; however, over time, social norms can adapt to modern life. India can foster and guide this process through government channeling. By adopting explicit and strict laws against CSA, India will send a message to its people and the world that CSA is illegal in India. Just one small step can help change the world.

322. Id.

323. See supra Part III.B.

324. E.g. Washington State, Guidelines for Child SeXual abuse InVestigations (1999) available at http://www.wsipp.wa.gov/rptfiles/childabusewrkgrp.pdf; K.C. FALLER, U.S. DEP'T OF HEALTH \& HUMAN SERvs., Investigations of Child Sexual Abuse in CHILD SEXUAL ABUSE: INTERVENTION \& TREATMENT ISSUES (1993) available at http://www.childwelfare.gov/ pubs/usermanuals/sexabuse/sexabused.cfm.

325. See VIRANI, supra note 86. 